\title{
Proximity to Hibernacula and Road Type Influence Potential Road Mortality of Snakes in Southwestern Saskatchewan
}

\author{
Ashley N. Fortney ${ }^{1}$, Ray G. Poulin ${ }^{1,2}$, Jessica A. Martino ${ }^{1}$, Dennilyn L. ParkeR ${ }^{3}$ and Christopher \\ M. SOMERS ${ }^{1,4}$
}

\author{
${ }^{1}$ Department of Biology, University of Regina, Regina, Saskatchewan S4S 0A2 Canada \\ ${ }^{2}$ Royal Saskatchewan Museum, Regina, Saskatchewan S4P 2V7 Canada \\ ${ }^{3}$ Western College of Veterinary Medicine, University of Saskatchewan, Saskatoon, Saskatchewan S7N 5B4 Canada \\ ${ }^{4}$ Corresponding author; email: chris.somers@uregina.ca
}
Fortney, Ashley N., Ray G. Poulin, Jessica A. Martino, Dennilyn L. Parker, and Christopher M. Somers. 2012. Proximity to hiber- nacula and road type influence potential road mortality of snakes in southwestern Saskatchewan. Canadian Field-Naturalist 126(3): 194-203.

The behaviour of snakes makes them vulnerable to road mortality, which may have conservation implications for some species. We examined factors affecting road mortality of snakes around Grasslands National Park of Canada (GNP), Saskatchewan, an area inhabited by a unique snake community within Canada, including the threatened Eastern Yellow-bellied Racer (Coluber constrictor flaviventris). Systematic surveys $(n=45)$ of roads in the Grasslands National Park area in 2009 yielded 36 dead and 18 live snakes. Multivariate modelling revealed that proximity to hibernacula was positively correlated with presence of snakes on roads. Paved roads had disproportionately higher numbers of snake mortalities, suggesting that traffic patterns are a bigger risk factor than road use per se. Some radio-tracked Eastern Yellow-bellied Racers (2 of 17; 12\%) and Bullsnakes (Pituophis catenifer sayi) (4 of 5; 80\%) captured at emergence from hibernacula had road areas in their home ranges. These individuals equipped with radio-transmitters used roads and immediately adjacent areas significantly more than expected, based on their availability, suggesting possible selection for roads. Strategies to reduce road mortality of snakes should focus on key stretches of roads, such as those near winter hibernacula or riparian zones. The placement of paved roads in sensitive areas like those in and around Grasslands National Park should be carefully considered to minimize snake mortality.

Key Words: Eastern Yellow-bellied Racer, Coluber constrictor flaviventris, Bullsnake, Pituophis catenifer sayi, Grasslands National Park of Canada, snake, road, mortality, habitat, Saskatchewan.

Roads can cause major changes to ecosystems and can have significant negative consequences for wildlife and biodiversity (Spellerberg 1998; Alexander and Waters 2000; Coffin 2007). Roads fragment habitat by presenting barriers to animal dispersal and cause spatial isolation of breeding groups (Ashley and Robinson 1996; Boarman et al. 1997; Epps et al. 2005; Row et al. 2007). In addition to landscape effects, roads can cause direct mortality of individuals via vehicle-animal collisions. For some taxa (e.g., deer, Odocoileus spp.), road mortality is fairly well understood and prevention measures are being tested and implemented (Foster and Humphrey 1995; Sullivan and Messmer 2003; Olsson and Widen 2008; Valitzski et al. 2009). However, for many taxa, broad knowledge of factors associated with road use and the consequences of road mortalities is lacking. Declines in reptile (class Reptilia) populations are occurring globally (Gibbons et al. 2000) and road mortality is a contributor for many species, yet our knowledge of the interactions of reptiles with roads lags behind that for other groups.

The ecology and behaviour of snakes (order Squamata) make them particularly vulnerable to road mortality (Andrews and Gibbons 2005). The heat-retaining properties of road surfaces may facilitate thermoregulation in snakes, causing them to bask in high-risk areas (Pienaar 1968; Ashley and Robinson 1996; Andrews et al. 2008; Shepard et al. 2008). Snakes are slowmoving relative to other vertebrates (Rosen and Lowe 1994), and cold snakes that seek roads to facilitate warming may be slow to escape approaching vehicles. Compounding this problem, many snake species use crypsis rather than flight as a defence mechanism. This means that they remain motionless on the road rather than moving away from an approaching vehicle (Andrews and Gibbons 2005). Snakes also have very long bodies, which present a relatively large target to be hit by vehicle tires. Widespread dislike of snakes by humans also increases the risk of snake mortality on roads because some drivers deliberately run over snakes with vehicles (Langley et al. 1989; Seburn and Seburn 2000; Jochimsen 2006; Ashley et al. 2007).

Snakes have a record of being neglected in management and conservation programs. Historically, reptiles have been one of the most under-represented taxonomic groups in major ecological journals and have received the lowest amount of funding by granting agencies (Gibbons 1988). Currently, 90\% of the reptilian species examined by COSEWIC have been classified as at risk, which is $20 \%$ higher than other vertebrate groups (COSEWIC 2012*). Although research on snakes has more recently been on the rise (Shine and Bonnet 2000), information to aid in their management and conservation is still largely lacking. 
Roads contribute significantly to mortality of snakes (Bonnet et al. 1999) and can greatly increase the probability of local extinction (Row et al. 2007). Populations of some snake species have declined or been extirpated in North America because of road mortality (Rosen and Lowe 1994; Rudolph et al. 1999; Row et al. 2007). For example, the abundance of larger snakes was reduced by more than $50 \%$ within $450 \mathrm{~m}$ of both a state highway (high traffic volume) and forest service system and county roads (lower traffic volume) in the Angelina National Forest in eastern Texas (Rudolph et al. 1999). Road mortality may be a significant threat to some Canadian snake populations, and data on road mortality are needed to facilitate conservation strategies.

The Grasslands National Park of Canada (GNP) area of southwestern Saskatchewan has a unique snake community within Canada. Six snake species occur there: Plains Gartersnake (Thamnophis radix), Wandering Gartersnake (Thamnophis elegans vagrans), Bullsnake (Pituophis catenifer sayi), Prairie Rattlesnake (Crotalus viridis), Eastern Yellow-bellied Racer (Coluber constrictor flaviventris), and Western Hog-nosed Snake (Heterodon nasicus).

At the time of this study, the Grasslands National Park area was one of only two locations in the country with a confirmed population of the Eastern Yellowbellied Racer (Gardiner et al. 2011), which is designated threatened by the Committee on the Status of Endangered Wildlife in Canada (COSEWIC) (COSEWIC 2004*) and under the federal Species at Risk Act. The Eastern Yellow-bellied Racer met the criteria to be considered for a designation of endangered, but was designated threatened because a large part of its habitat is in Grasslands National Park and there is rescue potential from Montana (COSEWIC 2004*). The Bullsnake is listed as data deficient by COSEWIC (COSEWIC $2002 *$ ), and the two gartersnake species, the Western Hog-nosed Snake, and the Prairie Rattlesnake have not been assessed by COSEWIC.

The development of a federal recovery strategy for the Eastern Yellow-bellied Racer requires the assessment of conservation threats, but no road mortality data for snakes in the Grasslands National Park area are currently available. Snakes, including Eastern Yellowbellied Racers, have been found dead on the roads in and around Grasslands National Park in the past, but the environmental factors contributing to the risk of mortality on roads have not been determined. Accordingly, in this study we used road surveys and radiotelemetry to examine factors that could have an impact on potential road mortality of snakes in southwestern Saskatchewan.

\section{Study Area and Methods \\ Study site}

This study was conducted near the town of Val Marie, Saskatchewan $\left(49^{\circ} 14^{\prime} \mathrm{N}, 107^{\circ} 43^{\prime} \mathrm{W}\right)$, and in the west block of Grasslands National Park (Figure 1). The major landscape feature of the area is the Frenchman River valley, which contains most of the known communal snake hibernacula (also referred to as dens). Two paved highways (two-lane, speed limit $100 \mathrm{~km} / \mathrm{h}$ ) and several gravel roads (speed limit $80 \mathrm{~km} / \mathrm{h}$ ) and trails (vehicle speeds $\sim 50 \mathrm{~km} / \mathrm{h}$ ) pass through the study area. The town of Val Marie has a population of less than 150 , the nearest city (Swift Current, population $\sim 15000$ ) is $120 \mathrm{~km}$ away, and Grasslands National Park receives only approximately 6000 visitors per year; thus, traffic volumes are relatively light. However, wildlife mortality on roads is still common in the area.

\section{Road surveys}

We conducted 45 road surveys in the study area between 6 May and 21 August 2009. Roads were chosen to cover a large area inside and outside Grasslands National Park. We surveyed three road types: paved surface, gravel surface, and trails (tracks through the grass with no surface material added). Roads were surveyed between 0600 and 1800 every two or three days. The total length of the survey route was $132 \mathrm{~km}$, consisting of $25 \mathrm{~km}$ of paved roads (19\%), $91 \mathrm{~km}$ of gravel roads (69\%), and $16 \mathrm{~km}$ of trails (12\%) (Figure 1).

We drove the complete route at speeds that enabled the complete road surface ahead of the vehicle to be scanned easily $(60-80 \mathrm{~km} / \mathrm{h}$ on the paved highways, $50-70 \mathrm{~km} / \mathrm{h}$ on gravel roads, and $30-50 \mathrm{~km} / \mathrm{h}$ on the trails). For all surveys, we drove at the low end of the speed range indicated unless required to speed up because of traffic. The driver was always accompanied by a second observer to improve snake detection.

When a snake was encountered, we recorded the road type and the snake's condition (dead or alive), and we noted its location using a hand-held global positioning system (GPS) (model eTrex Legend, Garmin Ltd., Olathe, Kansas). All dead snakes were collected and donated to the Royal Saskatchewan Museum in Regina, Sask.

\section{Impact of habitat on presence of snakes}

For road survey data, we employed a used versus available design to examine habitat variables that might influence snake presence/absence on roads. We designated the locations of snakes found on roads as used sites, and for comparison we generated an equal number of random available sites on the surveyed roads using a Geographical Information System (ArcGIS v. 9.2) (ESRI 2006*).

We calculated the distance in ArcGIS from each site that was used by snakes and from each available site to the nearest known communal snake hibernaculum and to the Frenchman River. Using the Southern Digital Land Cover dataset of the Saskatchewan Research Council (Saskatchewan Research Council $1995^{*}$ ), we also determined the proportion of water, exposed ground, urban area (including farm yards), 


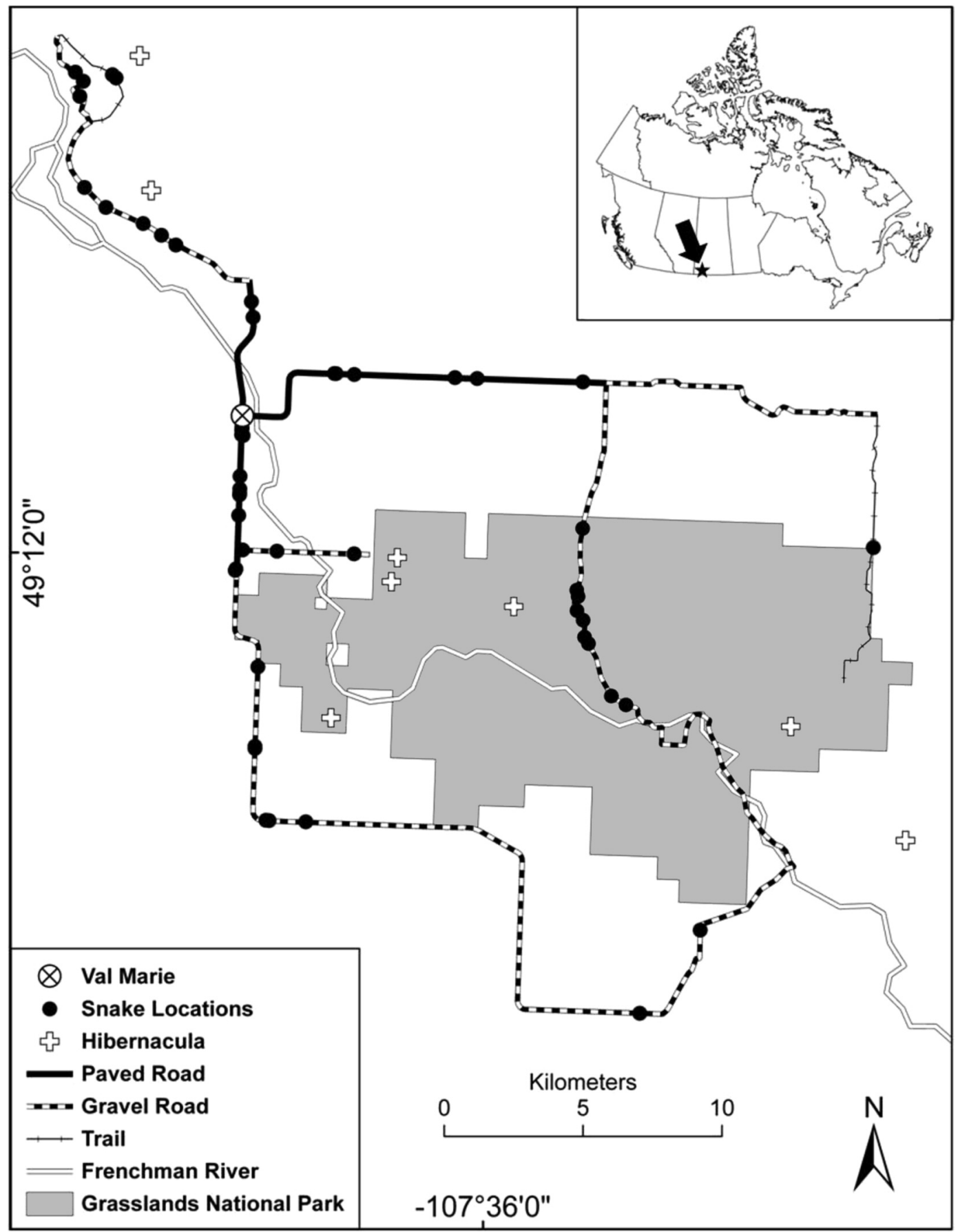

FIGURE 1. Study site surrounding Val Marie, Saskatchewan $\left(49^{\circ} 14^{\prime} \mathrm{N}, 107^{\circ} 43^{\prime} \mathrm{W}\right)$. 
shrubs, wetland, native grass, crop, hay, and woodland (i.e., habitat types) present within a 1-km radius of the sites that were used by snakes and the available sites. The 1-km radius, a common size in ecological studies, was chosen after initial univariate analyses of habitat variables indicated that a smaller radius $(400 \mathrm{~m})$ produced weaker relationships between snake use of roads and data variables (data not shown).

To determine the relationship between habitat and snake presence/absence, we analyzed road survey data using logistic regression to ascertain the -2 log likelihood (-2LL) for individual habitat variables. We also analyzed all possible variable combinations, with the exception of percentage cover of water, woodlands, and wetlands. The latter three variables were removed from analyses because in all cases the mean percentages for available locations and locations used by snakes were 0.0 (SD 0.0) and univariate analysis showed these variables were not good indicators of snake presence on roads. We also ascertained the $-2 \mathrm{LL}$ for the intercept-only model, which represents no impact of habitat on sites used by snakes (i.e., random).

We converted the -2LLs to Akaike's Information Criterion with a second-order correction for small samples (AIC ) (Hurvich and Tsai 1989). We ranked models according to $\mathrm{AIC}_{c}$ values to determine which variables best explained differences between sites used by snakes and available sites.

\section{Road use versus mortality}

We tested for differences in snake use of roads and mortality between road types (paved, gravel, and trail) using a $\chi^{2}$ contingency table analysis. We analyzed all snake locations, as well as locations of dead and live snakes separately, to determine whether snakes used road types proportionally based on availability and to determine whether there was a difference in mortality of snakes among road types. Specifically, of the total number of snakes found on roads, we expected to find $19 \%$ on paved, $69 \%$ on gravel, and $12 \%$ on trails, based on the proportion of each road type available. We also expected to find that dead and live snakes would be represented equally among road types if road type had no impact on snake mortality.

\section{Use of roads by individual snakes}

We used radio-telemetry to examine road use by Bullsnakes and Eastern Yellow-bellied Racers in the Grasslands National Park area. We captured 17 Eastern Yellow-bellied Racers and 3 Bullsnakes in the immediate vicinity of three known hibernacula, all of which are located at least $1 \mathrm{~km}$ from the nearest road. Two additional Bullsnakes that were known to overwinter in a den well removed from roads were captured slightly later in the season in a pasture area $<500 \mathrm{~m}$ from a gravel road.

All snakes were transported to the Western College of Veterinary Medicine at the University of Saskatchewan in Saskatoon, Saskatchewan, for surgical implan- tation of radio-transmitters (model SB-2, 4-5 g, Holohil Systems Ltd., Carp, Ontario.). For both species, transmitters were implanted only when the transmitter was $\leq 5 \%$ of snake body mass. We followed the surgical procedures outlined by Reinert and Cundall (1982), with the following modifications: $10-15$ minutes prior to inducing anaesthesia, snakes were given an intramuscular injection of buprenorphine at a dose of $0.01 \mathrm{mg} / \mathrm{kg}$ and snakes were also given an intramuscular injection of Meloxicam at a dose of $0.2 \mathrm{mg} / \mathrm{kg}$ as a post-operative analgesic.

We released snakes at their original point of capture and relocated them (receiver model R1000, Communication Specialists Inc., Orange, Calif.) approximately every two days between 17 May and 21 September 2009. When a snake was relocated, we recorded its location and the distance to the nearest road as greater than or less than $50 \mathrm{~m}$. Snakes within $50 \mathrm{~m}$ of a road were considered to be using the road area, because this distance is less than the average daily movement for these snakes, as determined by Martino et al. (2012).

For radio-telemetry data, we also employed a used versus available design. We first identified snakes whose home ranges, determined based on $100 \%$ minimum convex polygons (MCP), contained roads. We then used ArcGIS to calculate the proportion of road area (road area $=$ road $+50-\mathrm{m}$ buffer) within the home range, and we compared the proportion of time (days) spent by snakes within road areas to the total time tracked. A radio-tracked snake was considered to be in one location for the day that it was radio-tracked plus half the number of days between its previous and subsequent locations.

The percentage of days each individual snake spent in a road area was compared with the percentage of road area in its home range using a Wilcoxon signedrank test. If there was no correlation between roads and habitat use by snakes, the proportion of time spent in road areas would be equal to the proportion of the home range composed of road areas. We also performed this analysis on relocations directly by comparing the proportion of relocation points that were in road areas and the proportion of road in the home range.

\section{Results}

Road surveys

During 45 road surveys spanning the period 6 May to 21 August 2009 (a total distance surveyed of 5940 $\mathrm{km}$ of road surface), we found 54 snakes (36 dead and 18 live) (Table 1). The majority of snakes detected on roads were Prairie Rattlesnakes (43\%) and Plains Gartersnakes (37\%), followed by Bullsnakes (13\%) and Eastern Yellow-bellied Racers (7\%).

\section{Impact of habitat on presence of snakes}

The three top models that explained the difference between snake presence/absence on roads were (1) Distance to den + Road type + Percentage hay; (2) Distance to den + Road type; and (3) Distance to den + 
Road type + Distance to river (Table 2). On average, sites used by snakes were $1.4 \mathrm{~km}$ (SD 4.1) closer to dens (Figure 2A) and $2.6 \mathrm{~km}$ (SD 5.0) closer to the Frenchman River (Figure 2B) than random available sites. The use of gravel roads and trails was lower than the availability of these road types, and the use of paved roads was higher than the availability of such roads (see below).

The habitat variables Distance to den and Road type appeared in all three top models. This finding suggests that proximity to a hibernaculum and the kind of road (paved, gravel, or trail) are good predictors of potential road mortality of snakes. The amount of hay surrounding sites where snakes were present also appeared in the top model. The 1-km buffer surrounding sites used by snakes had double the amount of hay of random available points (Figure 2C).

\section{Road use versus mortality}

Multivariate modelling revealed that the percentage availability was different from the percentage use for each road type. Specifically, the number of used sites on gravel roads $(n=29)$ was $26 \%$ lower than the number of random available sites for such roads $(n=39)$. As well, the number of used sites on trails $(n=3)$ was $50 \%$ lower than the number of random available sites on trails $(n=6)$. In contrast, the number of used sites on paved roads ( $n=22$ ) was $244 \%$ higher than the number of random available sites on paved roads $(n=9)$.

To better discern the importance of road type, we also performed a $\chi^{2}$ analysis; this univariate analysis revealed that the locations of random available sites were not significantly different from expected, based on the proportions of road types surveyed $\left(\chi^{2}=0.287\right.$, df $=2, P=0.9)$. However, the total number of snakes found on paved roads, gravel roads, and trails was significantly different from expected, based on the proportions of road types surveyed (Table 1$)\left(\chi^{2}=16.8\right.$, $\mathrm{df}=2, P=0.0002)$, and more snakes were located on paved roads than expected.

The number of live snakes found on each road type was not different from expected (Figure 3A) $\left(\chi^{2}=0.726\right.$, df $\left.=2, P=0.7\right)$, but the number of dead snakes was significantly different from expected, based on available roads (Figure $3 \mathrm{~B})\left(\chi^{2}=22.2\right.$, df $=2, P<$ $0.0001)$. More than twice as many dead snakes were found on paved roads than expected $(50 \%$ of all detected), based on the proportion of this road type (19\%) in the survey area.

\section{Use of roads by individual snakes}

Roads ran through the home ranges of 2 of 17 (12\%) radio-tracked Eastern Yellow-bellied Racers and 4 of $5(80 \%)$ radio-tracked Bullsnakes. All snakes whose home ranges included road areas were found in road areas (on or within $50 \mathrm{~m}$ of the road) at least once during radio-tracking, with the exception of one Bullsnake. This individual had a road in its home range but was not located in the road area during radio-tracking.

In addition, all snakes whose home ranges included roads were located on both sides of the road during our study, with the exception of one Eastern Yellow-bellied Racer, confirming that they must have crossed the road. The Eastern Yellow-bellied Racer had a road in its home range and was located in the road area, but it was never located on the opposite side of the road during radio-

TABLE 1. Number of each snake species found dead or alive on the three road types near Val Marie, Saskatchewan.

\begin{tabular}{|c|c|c|c|c|c|c|c|c|c|}
\hline \multirow[t]{2}{*}{ Species } & \multicolumn{4}{|c|}{ Number of snakes found dead on: } & \multicolumn{4}{|c|}{ Number of snakes found alive on: } & \multirow[t]{2}{*}{ Total } \\
\hline & paved & gravel & trail & Subtotal & paved & gravel & trail & Subtotal & \\
\hline Crotalus viridis & 6 & 5 & 0 & 11 & 3 & 9 & 0 & 12 & 23 \\
\hline Thamnophis radix & 6 & 8 & 2 & 16 & 1 & 2 & 1 & 4 & 20 \\
\hline Pituophis catenifer sayi & 4 & 1 & 0 & 5 & 0 & 2 & 0 & 2 & 7 \\
\hline Coluber constrictor flaviventris & 2 & 2 & 0 & 4 & 0 & 0 & 0 & 0 & 4 \\
\hline Total & 18 & 16 & 2 & 36 & 4 & 13 & 1 & 18 & 54 \\
\hline
\end{tabular}

TABLE 2. Top three models identifying variables that best explain the difference between all locations where snakes were found (both dead and alive) and available locations on roads near Val Marie, Saskatchewan. All models explained the data set better than random when tested against the intercept-only model.

\begin{tabular}{lccccr}
\hline \hline Model & $\mathrm{K}^{\dagger}$ & $-2 \mathrm{LL}$ & $\Delta \mathrm{AIC}_{c}$ & Weight $^{\frac{\hbar}{*}}$ & Evidence ratio $^{\S}$ \\
\hline *Distance to den + Road type + Percentage hay & 5 & 127 & 0.00 & 0.45 & 1.00 \\
Distance to den + Road type & 4 & 130 & 0.91 & 0.29 & 1.58 \\
Distance to den + Road type + Distance to river & 5 & 128 & 1.12 & 0.26 & 1.75 \\
Intercept-only & 1 & 150 & 14.3 & $<0.01$ & 1270.00 \\
\hline \hline
\end{tabular}

*Top model

$\uparrow$ Number of parameters in each model

*Indicates the level of support for each model when compared with the top model and its competitors.

\$Indicates the magnitude at which the top model is better at explaining the data than the model indicated. 
tracking. The mean percentage of time that radiotracked snakes spent in road areas $(32 \%$, SD 25 ; range $0-65 \%$ ) was on average more than three times higher than expected, based on the proportion of home ranges made up of roads $(9 \%$, SD 5; range 4-16\% of the home range area).

Snake use of road areas within home ranges was similar when the proportion of relocation points in road areas was used in the analysis instead of time (data not shown). On average, radio-tracked Eastern Yellowbellied Racers spent 18\% (SD 2) of the time in road areas even though roads made up only 5\% (SD 1) of their home ranges, and radio-tracked Bullsnakes spent $39 \%$ (SD 25) of the time near roads despite the fact that roads constituted only $12 \%$ (SD 4 ) of their home ranges. The use of roads by snakes whose home ranges included roads was significantly higher than the percentage of area made up by the road (Wilcoxon signedrank test, $W=19, n=6, P<0.05)$.

\section{Discussion}

Our study indicates that proximity of roads to winter hibernacula is a key factor in the potential road mortality of snakes in the study area. Distance to den and Road type were the only habitat variables that were consistently present in top models, indicating that these variables best explain the difference between locations where snakes were present on roads and random available sites. This same result was found in a road mortality study of some ecologically similar snake species (Crotalus oreganus, Pituophis catenifer, Thamnophis elegans, and Coluber taeniatus) in Idaho (Jochimsen 2006).

Snakes often show high fidelity to hibernacula in temperate-zone areas (Brown and Parker 1976), so they are not likely to travel long distances from hibernaculum sites. Instead, most snakes will travel away from, or towards, the same den within the active season. Shepard et al. (2008) found that colubrid snakes experience higher numbers of road kills during seasonal periods that coincide with migration to and from hibernacula. The importance of winter hibernacula results in a higher concentration of snakes in the area surrounding a hibernaculum, and it explains the increased presence of snakes on roads closer to hibernacula than on roads farther away.

A second habitat variable that was potentially important was distance to the Frenchman River. The river valley contains all known snake hibernacula in the study area, so the Distance to river measurement may simply be a proxy for Distance to den. Alternatively, lowlands and riparian zones are important summer habitats for foraging and breeding Eastern Yellowbellied Racers and Bullsnakes in the study area (Martino et al. 2012), and this may result in higher snake numbers on roads near these habitats.

Conservation activities aimed at mitigating road mortality of snakes, such as road signs to alert drivers, could

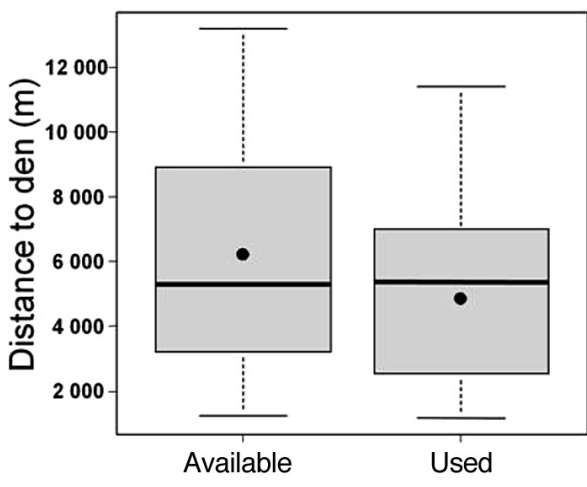

A)

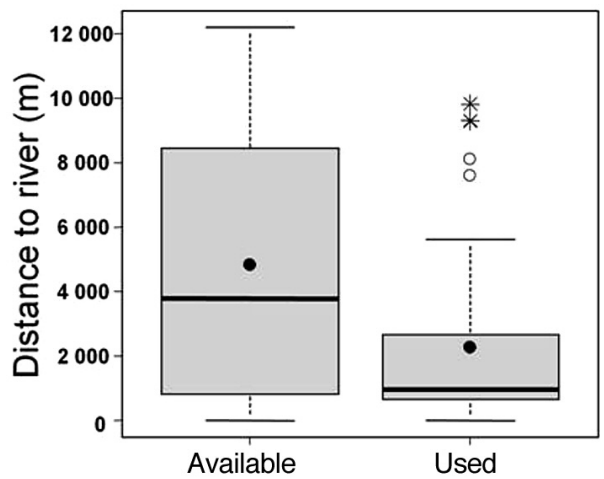

B)

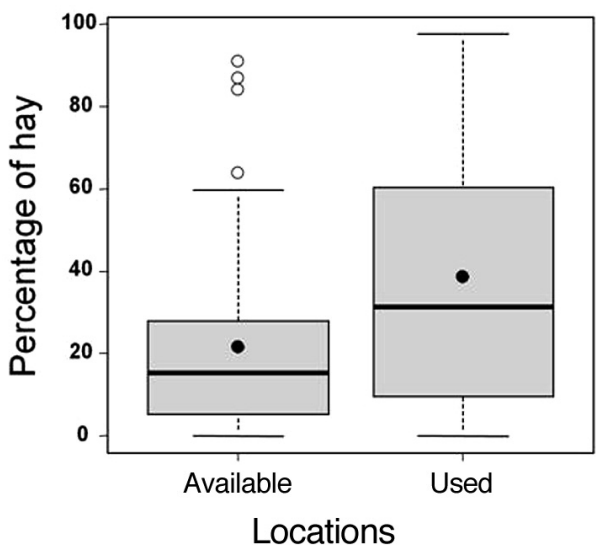

FIGURE 2. Box plots showing the distribution of values for habitat variables at all locations used by snakes (both dead and alive) and random available locations: A) Distance to den from random and all snake locations; B) Distance to river from random and all snake locations; C) Percentage of hay in a $1-\mathrm{km}$ radius surrounding random and all snake locations. Horizontal lines on the box plots represent the minimum value; the 25th, 50th (median), and 75th percentiles; and the maximum value. Filled circles represent the mean. Open circles represent minor outliers, which are observations 1.5 times the interquartile range (IQR) outside the central box, and asterisks represent major outliers, which are observations 3 times the interquartile range. 
be effectively focused on key stretches of roads near hibernacula and other important habitats (Shepard et al. 2008), such as riparian zones. Additionally, new roads in sensitive areas (e.g., for oil and gas development) (Walker et al. 2007) should be placed as far away as possible from riparian zones and known snake dens.

The composition of roadside habitats did not seem to have a major impact on snake presence on roads. With the exception of Percentage of hay, the variables related to vegetation that we measured were not useful predictors of potential snake mortality. The percentage of native grass did not explain differences between sites used by snakes and available sites. This finding was somewhat surprising, given that native prairie habitat is abundant close to den sites and in the Frenchman River valley (variables in the top models). Percentage of hay had a measurable influence only when it was included in a model with Distance to den and Road type.

We suggest three possible reasons for the inclusion of hay as a predictor variable in the top model only: (1) higher percentages of hay adjacent to roads may increase traffic volume associated with agricultural activities, thereby contributing to additional road mortality where snakes are already at elevated risk (on paved roads near hibernacula); (2) hay may have a biological value to snakes, such as increased availability of prey or access to refugia; or (3) Percentage of hay was not a truly informative predictor, but was included in the top model as a result of low penalties for additional variables that do not detract from the AIC model (Arnold 2010). We are unable to distinguish among these possibilities with our current data set, and suggest further inquiry into the potential ecological value of hay to snakes.

In our study, more road-killed snakes than expected were found on paved highways than on gravel roads or trails. Two potential explanations exist for this finding: (1) snakes are attracted to paved roads and use them more often than expected (e.g., for basking, as in Pienaar (1968) and Andrews et al. (2008)), thereby resulting in more vehicle encounters; or (2) snakes use paved roads in proportion to their availability but features of the road type make mortality events more likely.

Our analyses strongly favour the second explanation. We found no evidence that snakes were using any one road type disproportionately, i.e., the number of live snakes found on each type of road was as expected, based on availability of roads in our surveys. This suggests that snakes did not use paved roads more often than other road types; they were simply killed more often on paved surfaces. The most obvious differences between the paved roads and the other types in our study area are higher traffic volumes and higher vehicle speeds, both of which are likely major factors increasing the probability of snakes being killed (Roe et al. 2006).

Similar findings have been reported from road mortality studies in other areas (e.g., Rosen and Lowe
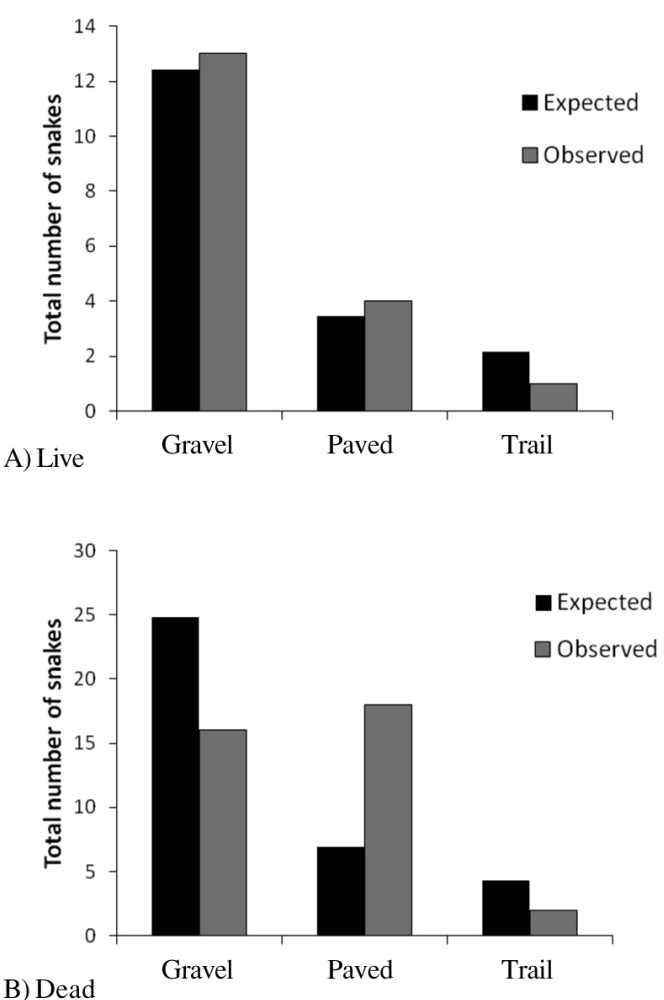

FIGURE 3. The number of snakes observed and expected, based on percentages of road type driven: A) live snakes and B) dead snakes. Dead snakes were found more than expected on paved roads.

1994; Clevenger et al. 2003), and they strongly suggest that paved roads deserve extra attention in conservation plans. For example, careful consideration should be given before gravel roads are upgraded to paved surfaces, and lower speed limits on existing and new paved roads may be required in sensitive areas. This would be beneficial to other taxa as well: a survey of road mortalities of species other than snakes in the study area also showed a greater than expected number of road kills taking place on paved roads than on other road types (Fortney 2010).

We encountered more dead and live Prairie Rattlesnakes than other species on roads. This implies that Prairie Rattlesnakes are more commonly found on roads, rather than that they are simply killed more often. This could be a reflection of a larger local population, or it could indicate that Prairie Rattlesnakes use or encounter roads more frequently than other species.

Differences in spatial use and movement patterns between species affect their risk of road mortality (Bonnet et al. 1999; Roe et al. 2006; Rouse et al. 2011). Venomous snakes may cross roads more slowly than other sympatric snake species because they have less 
pressure to cross open spaces quickly (due to their defence mechanism of venom). Venomous snakes may also employ a more defensive stance as a vehicle approaches instead of fleeing (Andrews and Gibbons 2005). Rattlesnakes also use crypsis as a defence mechanism, and this may cause them to immobilize when they are approached by a vehicle.

Bullsnakes and Eastern Yellow-bellied Racers were found least often, despite the fact that our radio-tracking data suggest that both species have a propensity to use road areas. Eastern Yellow-bellied Racers may have been found less frequently because they use speed as a defence mechanism (they cross roads more quickly than other species and thus avoid vehicles) (Andrews and Gibbons 2005); alternatively, Bullsnakes and Eastern Yellow-bellied Racers may use roadside areas more than they use the road itself. The lower numbers found could also be a result of smaller regional populations. Absolute population sizes have not been estimated for snakes in the study area, but our observations suggest that gartersnakes and Prairie Rattlesnakes are much more abundant than the other species.

Although our radio-telemetry sample size is small, our study indicates that roads may have a disproportionately larger impact on snakes than on other wildlife because (at least some) snakes appear to select habitat in road areas. Radio-tracking revealed that, when roads were within the home ranges of Eastern Yellow-bellied Racers or Bullsnakes, the snakes spent a greater amount of time on or near the roads than expected by chance.

Our data do not allow us to examine why snakes select or do not select road areas. However, we offer the following potential explanations: (1) snakes are attracted to roads for use in thermoregulation (e.g., Klauber 1939; Pienaar 1968; Sullivan 1981; Andrews et al. 2008); (2) roadside ditches offer conditions that enhance prey resources (Bellamy et al. 2000; Rytwinski and Fahrig 2007); and (3) some snakes may be unwilling or unable to cross roads and are essentially isolated in adjacent habitats (e.g., Richardson et al. 2006; Rouse et al. 2011). Regardless of the underlying explanation, selection for road areas by snakes likely elevates their risk of road mortality well beyond what would be predicted based on the assumption that they encounter roads randomly based on availability.

Snakes that perceive roads as barriers and move alongside them instead of crossing them (e.g., Prairie Kingsnake, Lampropeltis calligaster calligaster) (Richardson et al. 2006) avoid the risk of encountering vehicles but may still be negatively affected by a number of other habitat fragmentation effects associated with roads (e.g., Kjoss and Litvaitis 2001). Conservation planning for snakes should therefore include both potential habitat selection for roads as an elevated risk factor for road mortality and the indirect effects of roads (e.g., habitat fragmentation). To provide insight into how road mortality risks to snakes can potentially be minimized, future studies should address why snakes select habitat near roads.

Our study has three main results of conservation and management relevance: (1) the probability of finding live or dead snakes on a road of any type is determined largely by the proximity of the road to a hibernaculum or to a river; (2) snakes do not show a preference for any one road type, but those that use paved roads are more likely to be killed by a vehicle; and (3) when a snake's home range includes roads, the road area is used more than expected by chance. We recommend further investigation to verify this third result using a larger sample size. We also suggest additional studies that examine long-term, seasonal, and sex-specific trends in road mortality.

The community of grassland snakes in the Grasslands National Park area is unique in Canada, and these results should be employed in conservation strategies to maintain this community. The information may also be useful to mitigate road mortality of snakes in other areas.

\section{Acknowledgements}

We thank the Natural Sciences and Engineering Research Council of Canada, the Canada Research Chairs Program, Grasslands National Park, the Parks Canada Agency, the Royal Saskatchewan Museum, the Friends of the Royal Saskatchewan Museum, the Fish and Wildlife Development Fund of Saskatchewan Environment, the Interdepartmental Recovery Fund of Environment Canada, the Canadian Wildlife Federation, and the Canadian Museum of Nature for financial support. We also thank the University of Regina President's Committee on Animal Care, the Saskatchewan Ministry of the Environment, Environment Canada, the Parks Canada Agency, and Agriculture and Agri-Food Canada for issuing the required approval and permits to conduct this research. We also thank H. Sauder and J. Meaden for assistance with field work.

Documents Cited (marked $*$ in text)

COSEWIC. 2002. COSEWIC assessment and status report on the Gophersnake Pituophis catenifer in Canada. Committee on the Status of Endangered Wildlife in Canada, Ottawa, Ontario. vii + 33 pages.

COSEWIC. 2004. COSEWIC assessment and update status report on the Eastern and Western Yellow-bellied Racers, Coluber constrictor flaviventris and Coluber constrictor mormon in Canada. Committee on the Status of Endangered Wildlife in Canada, Ottawa, Ontario. vii + 35 pages.

COSEWIC. 2012. Canadian wildlife species at risk. Committee on the Status of Endangered Wildlife in Canada, Ottawa, Ontario. 98 pages.

ESRI. 2006. ArcGIS 9.2. Environmental Systems Research Institute, Redlands, California.

Saskatchewan Research Council. 1995. Southern Digital Land Cover (SDLC). Saskatchewan Research Council, Saskatoon, Saskatchewan. 


\section{Literature Cited}

Alexander, S. M., and N. M. Waters. 2000. The effects of highway transportation corridors on wildlife: a case study of Banff National Park. Transportation Research Part C: Emerging Technologies 8: 307-320.

Andrews, K. M., and J. W. Gibbons. 2005. How do highways influence snake movement? Behavioural responses to roads and vehicles. Copeia 2005: 772-782.

Andrews, K. M., J. W. Gibbons, and D. M. Jochimsen. 2008. Ecological effects of roads on amphibians and reptiles: a literature review. Pages 121-143 in Urban Herpetology. Edited by J. C. Mitchell, R. E. Brown, and B. Bartholemew. Herpetological Conservation No. 3. Society for the Study of Amphibians and Reptiles, Salt Lake City, Utah.

Arnold, T. W. 2010. Uninformative parameters and model selection using Akaike's information criterion. Journal of Wildlife Management 74: 1175-1178.

Ashley, P. E., and J. T. Robinson. 1996. Road mortality of amphibians, reptiles and other wildlife on the Long Point Causeway, Lake Erie, Ontario. Canadian Field-Naturalist 110: 403-412.

Ashley, P. E., A. Kosloski, and S. A. Petrie. 2007. Incidence of intentional vehicle-reptile collisions. Human Dimensions of Wildlife 12: 137-143.

Bellamy, P. E., R. F. Shore, D. Ardeshir, J. R. Treweek, and T. H. Sparks. 2000. Road verges as habitat for small mammals in Britain. Mammal Review 30: 131-139.

Boarman, W. I., M. Sazaki, and W. B. Jennings. 1997. The effect of roads, barrier fences, and culverts on desert tortoise populations in California, USA. Pages 54-58 in Proceedings: Conservation, Restoration, and Management of Tortoises and Turtles-An International Conference, 1116 July 1993, State University of New York at Purchase. New York Turtle and Tortoise Society, New York, and the Wildlife Conservation Society, Bronx, New York.

Bonnet, X., G. Naulleau, and R. Shine. 1999. The dangers of leaving home: dispersal and mortality in snakes. Biological Conservation 89: 39-50.

Brown, W. S., and W. S. Parker. 1976. Movement ecology of Coluber constrictor near communal hibernacula. Copeia 1976: 225-242.

Clevenger, A. P., B. Chruszcz, and K. E. Gunson. 2003. Spatial patterns and factors influencing small vertebrate fauna road-kill aggregations. Biological Conservation 109: $15-26$.

Coffin, A. W. 2007. From roadkill to road ecology: a review of the ecological effects of roads. Journal of Transport Geography 15: 396-406.

Epps, C. W., P. J. Palsboll, J. D. Wehausen, G. K. Roderick, R. R. Ramey II, and D. R. McCullough. 2005. Highways block gene flow and cause a rapid decline in genetic diversity of desert bighorn sheep. Ecology Letters 8: 1029-1038.

Fortney, A. F. 2010. Road mortality survey in southwestern Saskatchewan. Blue Jay 68: 95-98.

Foster, M. L., and S. R. Humphrey. 1995. Use of highway underpasses by Florida panthers and other wildlife. Wildlife Society Bulletin 23: 95-100.

Gardiner L. E., J. A. Martino, R. G. Poulin, and C. M. Somers. 2011. Eastern yellow-bellied racer populations on the Canadian prairies. Blue Jay 69: 70-74.

Gibbons, J. W. 1988. The management of amphibians, reptiles, and small mammals in North America: the need for an environmental attitude adjustment. Pages 4-10 in Man- agement of Amphibians, Reptiles, and Small Mammals in North America. Edited by R. C. Szaro, K. E. Severson, and D. R. Patton. USDA Forest Service, Flagstaff, Arizona.

Gibbons, J. W., D. E. Scott, T. J. Ryan, K. A. Buhlmann, T. D. Tuberville, B. S. Metts, J. L. Greene, T. Mills, Y. Leiden, S. Poppy, and C. T. Winne. 2000. The global decline of reptiles, déjà vu amphibians. BioScience 50: 653-666.

Hurvich, C. M., and C-L. Tsai. 1989. Regression and time series model selection in small samples. Biometrika 76: 297-307.

Jochimsen, D. M. 2006. Factors influencing the road mortality of snakes on the Upper Snake River Plain, Idaho. Pages 351-365 in Proceedings of the 2005 International Conference on Ecology and Transportation, August 29September 2, 2005, San Diego, California. Edited by Leroy Irwin, Paul Garrett, and K. P. McDermott. Center for Transportation and the Environment, North Carolina State University, Raleigh, North Carolina.

Kjoss, V. A., and J. A. Litvaitis. 2001. Community structure of snakes in a human-dominated landscape. Biological Conservation 98: 285-292.

Klauber, L. M. 1939. Studies of reptile life in the arid Southwest. Bulletin of the Zoological Society of San Diego 14: $1-54$.

Langley, W. M., H. W. Lipps, and J. F. Theis. 1989. Responses of Kansas motorists to snake models on a rural highway. Transactions of the Kansas Academy of Science 92: 43-48.

Martino, J. A., R. G. Poulin, D. L. Parker, and C. M. Somers. 2012. Habitat selection by grassland snakes at northern range limits: implications for conservation. Journal of Wildlife Management 76: 759-767.

Olsson, M. P. O., and P. Widen. 2008. Effects of highway fencing and wildlife crossings on moose Alces alces movements and space use in southwestern Sweden. Wildlife Biology 14: 111-117.

Pienaar, U. de V. 1968. The ecological significance of roads in a national park. Koedoe: African Protected Area Conservation and Science 11: 169-174.

Reinert, H. K., and D. Cundall. 1982. An improved surgical implantation method for radio-tracking snakes. Copeia 1982: 702-705.

Richardson, M. L., P. J. Weatherhead, and J. D. Brawn. 2006. Habitat use and activity of prairie kingsnakes (Lampropeltis calligaster calligaster) in Illinois. Journal of Herpetology 40: 423-428.

Roe, J. H., J. Gibson, and B. A. Kingsbury. 2006. Beyond the wetland border: estimating the impact of roads for two species of water snakes. Biological Conservation 130: 161168.

Rosen, P. C., and C. H. Lowe. 1994. Highway mortality of snakes in the Sonoran Desert of southern Arizona. Biological Conservation 68: 143-148.

Rouse, J. D., R. J. Willson, R. Black, and R. J. Brooks. 2011. Movement and spatial dispersion of Sistrurus catenatus and Heterodon platirhinos: implications for interactions with roads. Copeia 2011: 443-456.

Row, J. R., G. Blouin-Demers, and P. J. Weatherhead. 2007. Demographic effects of road mortality in black ratsnakes (Elaphe obsoleta). Biological Conservation 137: 117-124.

Rudolph, D. C., S. J. Burgdorf, R. N. Conner, and R. R. Schaefer. 1999. Preliminary evaluation of the impact of 
roads and associated vehicular traffic on snake populations in eastern Texas. Pages 128-135 in Proceedings of the Third International Conference on Wildlife Ecology and Transportation, September 13-16, 1999, Missoula, Montana. Edited by Gary L. Evink, Paul Garrett, and David Zeigler. Florida Department of Transportation, Tallahassee, Florida.

Rytwinski, T., and L. Fahrig. 2007. Effect of road density on abundance of white-footed mice. Landscape Ecology 22: 1501-1512.

Seburn, D., and C. Seburn. 2000. Conservation priorities for the amphibians and reptiles of Canada. World Wildlife Fund Canada and the Canadian Amphibian and Reptile Conservation Network. World Wildlife Fund Canada, Toronto, Ontario. 92 pages.

Shepard, D. B., M. J. Dreslik, B. C. Jellen, and C. A. Phillips. 2008. Reptile road mortality around an oasis in the Illinois corn desert with emphasis on the endangered eastern massasauga. Copeia 2008: 350-359.

Shine, R., and X. Bonnet. 2000. Snakes: a new 'model organism' in ecological research? Trends in Ecology and Evolution 15: 221-222.
Spellerberg, I. F. 1998. Ecological effects of roads and traffic: a literature review. Global Ecology and Biogeography 7: 317-333.

Sullivan, B. K. 1981. Observed differences in body temperature and associated behaviour of four snake species. Journal of Herpetology 15: 245-246.

Sullivan, T. L., and T. A. Messmer. 2003. Perceptions of deer-vehicle collision management by state wildlife agency and department of transportation administrators. Wildlife Society Bulletin 31: 163-173.

Valitzski, S. A., G. J. D'Angelo, G. R. Gallagher, D. A. Osborn, K. V. Miller, and R. J. Warren. 2009. Deer responses to sounds from a vehicle-mounted soundproduction system. Journal of Wildlife Management 73: 1072-1077.

Walker, B. L., D. E. Naugle, and K. E. Doherty. 2007. Greater sage-grouse population response to energy development and habitat loss. Journal of Wildlife Management 71: 2644-2654.

Received 27 April 2012

Accepted 11 September 2012 